\title{
DIGITAL PRODUCT FEATURE PRIORITIZATION - CONCEPTUAL FRAMEWORKS
}

\author{
${ }^{* 1}$ Dr. Pon Meenakshi, ${ }^{2}$ Siva Karthikeyan Krishnan, ${ }^{3}$ R Rajkumar \\ ${ }^{*}$ Associate Professor, Department of Management Studies (PG), Sri Ramakrishna \\ college of Arts and science, Coimbatore-641006 \\ ${ }^{2}$ Research Scholar, Department of Management Studies (PG), Sri Ramakrishna College \\ of Arts and Science, Coimbatore-641006 \\ ${ }^{3}$ Assistant Professor, Department of CSE, SRM Institute of Science and Technology, \\ Kattankulathur, India.
}

\begin{abstract}
Product Feature prioritization is a key challenge the current day startup faces. With lot of startups evolving in India, startups developing digital products struggle to identify what features to be developed in early stages. Products with right features which have productmarket fit at right timing is key factor for product success. Startup founders and product managers struggle in finding appropriate methodology or framework to prioritize product features. This paper explores the conceptual frameworks available and its application in realworld which can help founders and startup choose their right ones.
\end{abstract}

Keywords: Prioritization Frameworks, Product Roadmap, Startups, Product Features

\section{INTRODUCTION}

"Digital Product" - Digital product can be defined a product which does not necessarily have a physical form or substance (Website, Software Applications, Mobile Apps), yet this definition is slowly changing. Why? The advent of concepts like Internet of Things are redefining the digital product as they slowly tend to be more connected and provided data as insights from physical product - so ideally it means all electronic data.

Product feature prioritization could be different from requirement prioritization, yet requirement prioritization would be the subset of feature prioritization. Features would bundle or encompass various set of requirements. Features are meant to be published or advertised for marketing of the product yet they need to be built with appropriate focus based on prioritization. Startups and product managers of the organization has limited resources such as people, time and money for development of the products. Prioritization of the features to be developed for a digital product is recognized as an important activity during the development yet it's a challenging one. Especially managing the features to be part of a specific release, becomes very complex when there is pressing need to go to market with right product-market fit. (J. Karlsson \& Ryan, 1997; Joachim Karlsson, Wohlin, \& Regnell, 1998).

Developing the digital products with specific features with correct product-market fit in the right time is always a challenge. It's very evident the product prioritization which will the 
product market fit is the biggest challenge the industry faces today.('The biggest challenge for product managers?', 2016) conducted among 47 Product managers on the Enterprise Software, Consumer Software, Business Consulting and other services segment. ( Figure 1: What's your \#1 single biggest product management challenge right now?). There are many ways in which this problem can be resolved with various set of prioritization techniques('20 Product Prioritization Techniques', n.d.).

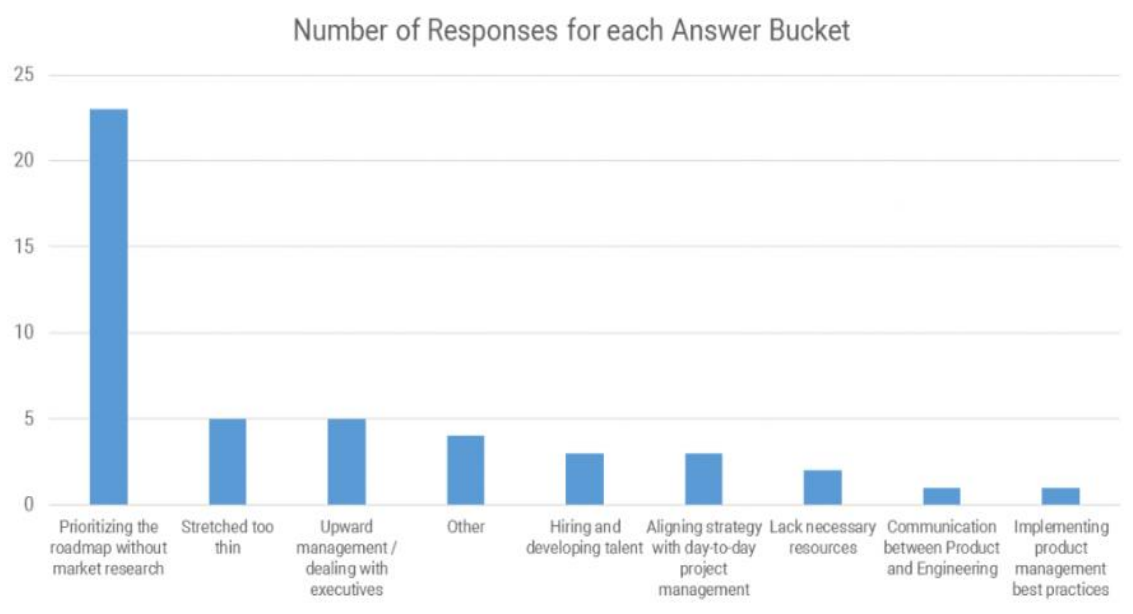

Figure 1: What's your \#1 single biggest product management challenge right now?

In the recent requirements engineering workshop done in Germany it's found sthat systemization and determination are outlined as the major factor for optimizing the future, which starts with determining or prioritizing what to develop in the first place. ('Rückblick 2019', 2018). This cannot be emphasized enough as the key area for developing the right product in alignment with the customer satisfaction metrics. $75 \%$ of the respondents agreed for a need for methodologically correct comprehensive modeling is time consuming and requires large capacity. The early phases prioritization is biased and subjective of the individual opinions. It also outlined the need for continuous validation of the prioritized dimensions. These survey findings explicitly indicate that there is a need for improved ways for prioritizing the requirements and also which needs to be aligned with product market fit.

As product feature prioritization is the core of product development go to market story and its essential component in decision making (Dingsøyr, Hanssen, Dybå, Anker, \& Nygaard, 2006). Product feature prioritization can be primarily categorized into two major categories one is based on methods and other based on negotiation. Negotiation revolves around the stakeholder viewpoints. Methods helps to approach the problem in a quantitative way.

\section{PROBLEM DEFINITION}

The startups/Product development organization find it difficult to convince the investors or stakeholders on the features planned for a specific release of digital product. The stakeholders would be in a comfortable position if the presentation or rationale for the choice of features are corroborated with data and insights for easy decision making. The prioritization of the features to be developed for the product to be developed would be more focused without much 
deviation. (Crowne, 2002; Giardino, Wang, \& Abrahamsson, 2014) What is the strategy to be adopted to prioritize the features of the product? What are the conceptual frameworks available for the startups to make the right choices with limited inputs and constraints in terms of size of organization? Are there any such frameworks available to help decide on the features to be developed once you eloped into the core idea of the product. This research paper attempts to find answers to those questions as objectives.

\subsection{Objective}

This paper researches existing prioritization frameworks. It specifically tries to address the digital product. It primarily tries to find answers to the following questions:

- What are the existing surveys or efforts made in literature on the digital product features prioritization frameworks?

- What are the frameworks or methodologies available for prioritizing product features which can help the product organizations/startups?

- Which are factors helpful in helping to choose the framework in what context?

Finally, to arrive at a visual taxonomy for startups or other organizations to quickly understand the prioritization frameworks available as choices. This selection of prioritization frameworks would help in building the product roadmap furthering development and mobilization of resources.

\subsection{Related Works:}

In 1997, Joachim Karlsson evaluated 6 different methods for prioritizing software requirements. This was done for a telephone system. The 6 different methods for Analytics Hierarchy Process, Hierarchy AHP, Minimal spanning Tree, Bubble Sort, Binary search and Priority Groups these more like algorithms. Evaluation was done based on Ratio and Ordinality. The paper concluded the AHP process is suitable for prioritization but it could be problematic for large projects. (Joachim Karlsson et al, 1998)

In 2006, Karlssson investigated differences between the scales used in prioritization. Generally, techniques which has richer scales is time consuming and complex to use. The research focused on Skewness measure helps to determine the cases where ratio scale would be meaningful. Identified the importance of Cost-Value approach which takes both the implementation cost and customer value into account. It discusses the different Scales - Nominal, Ordinal, Interval and Ratio Methods used in prioritization techniques. It evaluated Numeral assignment, Planning game, \$100 test, Wiegers' method, and Pair-wise comparisons. Finally recommends to perform case studies on adoption of prioritization methods, perform controlled experiments and conduct interview survey with the leaders and product managers practicing for validation.(L. Karlsson, 2006)

In the 2013, Wiegers, Karl Eugene, and Joy Beatty in Chapter 16 discusses the various requirement prioritization techniques. They recommended that requirement prioritization techniques help to avoid aspects of emotion, politics and guesswork as part of the process. They also insist upon avoid knee-jerk reactions to the customer needs rather focus on 
prioritizing the features to be built. Methods were suggested based on the relative value and relative cost of each requirement. (Wiegers \& Beatty, 2013)

In 2017, Raneem Qaddoura discussed how data mining and machine learning techniques are being used in prioritizing requirements in digital products. It evaluated various methods such as AHP, BST, Numeral Assignment Technique, MST, Planning game, Hundred Dollar Method, Theory-W, Priority Groups and Bubble Sort. Finally the research evaluate the methods based on High, Medium and Low scale on the criteria such as Complexity, Ease of Use, Reliability of Results, Fault Tolerance, Speed and Number of requirements. (Qaddoura, AbuSrhan, Qasem, \& Hudaib, 2017)

In 2018, Amjad Hudaib elucidates various prioritization techniques proposed by researchers which grouped by Ratio, Ordinality and Nominal categories. It focusses on functional and nonfunctional requirements prioritization in relation to products success and quality. The comparison has been done based on Preparation Stage, Execution Stage and Presentation stage. Evaluation done based on Ease of use, Speed, Certainty, Scalability, Accuracy. There results were evaluated based on these criteria and finally it suggested Binary search Tree for a specific use case. It also discussed the pros and cons of the methods evaluated. They recommended IPA - Integrated Prioritization Approach which consists of a 5-step process to generate a decision matrix for prioritizing requirements. (Hudaib, Masadeh, Qasem, \& Alzaqebah, 2018)

In 2020, Varun Gupta shared the findings of systematic mapping study which specifically focused on requirements engineering in startup. It presented the analysis of literature availability on product requirements engineering with the startup context. It looked at support from research literature which can help in increasing their success rate. The specific focus was at product-market fit. It outlined that there was clear lack of focus on this area during the period 2017,2018 and 2019. It's evident that requirement prioritization was at 5\% with respect to the IEEE Explore, ACM, Springer and ScienceDirect during this period. It concluded with an important note that research needs to support the startups by providing solutions for building right product roadmaps, prioritizing the right features with evidence to support decision makings, best practices and sharing of experiences that are adoptable in their real context. (Gupta, Fernandez-Crehuet, Hanne, \& Telesko, 2020)

\subsection{Motivations}

To achieve our objectives and to drive the study we formulate the following research questions: RQ1: What are the existing surveys or efforts made in literature on the product features prioritization frameworks?

Motivation: To understand the availability of extensive study and efforts on product feature prioritization and its help in building product with better product-market fit. Better prioritization of the features should lead to better results. The goal is to find what research community shares on the prioritization methods and frameworks. Finding inputs on the existing research leads or paves way to the next question RQ2.

RQ2: What are the frameworks or methodologies available for prioritizing product features which can help the product organizations/startups? 
Motivation: Primarily to help the startups to have an understanding on the broad choices available for them to make on prioritization frameworks in the recent trends. May be the advent of agile, lean methodologies could have influenced additional frameworks than in the past. Having a taxonomical understanding of the existing framework would be very useful in selection of framework. But that won't be sufficient, the startups or product organization needs to understand what factors could influence the selection of frameworks which leads to RQ3:

RQ3: Which are factors helpful in helping to choose the framework in what context?

Motivation: Identify the factors which has been adopted in the past and identify any relevance in the feature prioritization context. Outline why those factors would be key contributing factor to the selection of framework.

\section{METHODOLOGY}

For answering the research objectives, the goal is to arrive at the list of existing feature prioritization methods. Following are the different set of sources used for the research: Google Scholar, Website and blogs of product road mapping tools (productplan.com), interactions specifically done on twitter about the prioritization frameworks, books related to the software engineering, whitepapers available in product sites and its references.

\section{FINDINGS}

This goal of this search is focus on prioritizing the features or requirements of the digital products. It should extract all the existing methods which are being adopted in the industry so that the startups or product organization has an exhaustive set of choices to select. (Wiegers \& Beatty, 2013). The research methods which were discussed in the existing research were Moscow, 100\$, Analytics Hierarchy Process, Cost-Value based approach since 1997. (J. Karlsson \& Ryan, 1997). There has been discussion on the various factors to be used to evaluate the prioritization frameworks available which includes complexity, ease of use, etc., (Qaddoura et al, 2017). It's clearly indicated that product feature or product requirement prioritization has lacked focus in the recent year 2017,2018 and 2019. (Gupta et al, 2020). So, there is a need for holistically looking at building a list of prioritization frameworks with latest addendum which would help product organizations to look at the frameworks and help move forward in using them appropriately.

\section{IDENTIFIED PRIORITIZATION FRAMEWORKS:}

In the process of finding various frameworks listed down the 10 frameworks with Input, Process and Output. This table would help to understand the potential inputs required for selection of the framework. 
Table 1: Prioritization Frameworks

\begin{tabular}{|c|c|c|c|c|c|}
\hline S.no & Framework & Description & Input & Process & Output \\
\hline 1 & $\begin{array}{c}\text { Kano(kano, } \\
\text { 1984) }\end{array}$ & $\begin{array}{l}\text { Framework for } \\
\text { prioritizing the } \\
\text { features for } \\
\text { customer } \\
\text { satisfaction to } \\
\text { delight for } \\
\text { functionality }\end{array}$ & $\begin{array}{l}\text { Features } \\
\text { Categorization } \\
\text { of features } \\
\text { Survey } \\
\text { questions }\end{array}$ & Survey & $\begin{array}{l}\text { Discrete score } \\
\text { mapped in kano } \\
\text { categorization }\end{array}$ \\
\hline 2 & $\begin{array}{l}\text { Rice (reach, } \\
\text { effort, impact } \\
\text { and } \\
\text { confidence) }\end{array}$ & $\begin{array}{l}\text { Evaluate each of } \\
\text { your competing } \\
\text { features based on } 4 \\
\text { factors }\end{array}$ & $\begin{array}{l}\text { Scores based on } \\
\text { reach, effort, } \\
\text { impact and } \\
\text { confidence }\end{array}$ & $\begin{array}{l}\text { Survey for } \\
\text { scoring }\end{array}$ & $\begin{array}{c}\text { Rice score }= \\
\text { (reach x impact } \\
\text { x confidence) / } \\
\quad \text { effort }\end{array}$ \\
\hline 3 & $\begin{array}{l}\text { Cod (cost of } \\
\text { delay) }\end{array}$ & $\begin{array}{l}\text { Prioritizing based } \\
\text { on the cost of delay }\end{array}$ & $\begin{array}{c}\text { Feature, } \\
\text { duration, value }\end{array}$ & $\begin{array}{l}\text { Cost of } \\
\text { delay/dura } \\
\text { tion }\end{array}$ & $\begin{array}{c}\text { Prioritization as } \\
\text { no priority, } \\
\text { duration } \\
\text { priority, value } \\
\text { priority, cd3 } \\
\text { priority }\end{array}$ \\
\hline 4 & $\begin{array}{c}\text { WSJF } \\
\text { (weighted } \\
\text { shortest job } \\
\text { first) }\end{array}$ & $\begin{array}{l}\text { Prioritizing the } \\
\text { product features } \\
\text { according to } \\
\text { their weight }\end{array}$ & $\begin{array}{l}\mathrm{Cd} 3 \text {, safe-style, } \\
\text { time horizon- } \\
\text { based weighting, } \\
\text { size of each job }\end{array}$ & $\begin{array}{c}\text { Can be } \\
\text { made with } \\
\text { spreadshee } \\
\text { t }\end{array}$ & $\begin{array}{l}\text { Calculated } \\
\text { priorities }\end{array}$ \\
\hline 5 & $\begin{array}{l}\text { Hippo } \\
\text { (highest paid } \\
\text { person's } \\
\text { opinion) }\end{array}$ & $\begin{array}{l}\text { Priorities are set by } \\
\text { influential } \\
\text { stakeholder based } \\
\text { on gut and } \\
\text { experience rather } \\
\text { than actual } \\
\text { underlying data }\end{array}$ & $\begin{array}{c}\text { Inputs on } \\
\text { prioritization } \\
\text { features based } \\
\text { on gut feel }\end{array}$ & $\begin{array}{l}\text { Discussion } \\
\text { forums, } \\
\text { product } \\
\text { discussion } \\
\mathrm{s}\end{array}$ & $\begin{array}{c}\text { Prioritized } \\
\text { features based } \\
\text { on raw inputs } \\
\text { influenced by } \\
\text { power and } \\
\text { politics }\end{array}$ \\
\hline 6 & $\begin{array}{c}\text { Impact vs } \\
\text { effort } \\
\text { prioritization }\end{array}$ & $\begin{array}{c}2 \text { by } 2 \text { matrix } \\
\text { comparing impact } \\
\text { vs effort }\end{array}$ & $\begin{array}{l}\text { Impact rating, } \\
\text { effort rating on a } \\
\text { 10-point scale }\end{array}$ & $\begin{array}{l}\text { Event } \\
\text { storming, } \\
\text { impact } \\
\text { mapping, } \\
\text { hmw, user } \\
\text { research, } \\
\text { empathy } \\
\text { mapping }\end{array}$ & $\begin{array}{l}\text { 4-quadrant chart } \\
\text { low-effort and } \\
\text { impact, high- } \\
\text { effort and low- } \\
\text { impact, low- } \\
\text { impact and high- } \\
\text { effort, and high- } \\
\text { impact and } \\
\text { effort. }\end{array}$ \\
\hline
\end{tabular}




\begin{tabular}{|c|c|c|c|c|c|}
\hline 7 & $\begin{array}{l}\text { Custom } \\
\text { weighted } \\
\text { scoring }\end{array}$ & $\begin{array}{l}\text { Customized factors } \\
\text { for scoring }\end{array}$ & Benefits cost & $\begin{array}{l}\text { Scoring of } \\
\text { the } \\
\text { benefits on } \\
\text { value and } \\
\text { cost on } \\
\text { efforts }\end{array}$ & $\begin{array}{l}\text { Weighted } \\
\text { scoring priority } \\
\text { matrix }\end{array}$ \\
\hline 8 & $\begin{array}{l}\text { Opportunity } \\
\text { Scoring } \\
\text { (Ulwick, n.d.) }\end{array}$ & $\begin{array}{l}\text { Helps to spotlight } \\
\text { on the features that } \\
\text { users deem most } \\
\text { important and most } \\
\text { satisfying }\end{array}$ & $\begin{array}{l}\text { Scoring on } \\
\text { Important and } \\
\text { Satisfying } \\
\text { features }\end{array}$ & $\begin{array}{l}\text { Opportunit } \\
\mathrm{y}= \\
\text { Importanc } \\
\mathrm{e}+ \\
\text { (Importan } \\
\text { ce- } \\
\text { Satisfactio } \\
\mathrm{n} \text { ) } \\
\end{array}$ & $\begin{array}{c}\text { Mapping the } \\
\text { opportunity } \\
\text { score in a graph } \\
\text { against } \\
\text { outcomes which } \\
\text { is underserved } \\
\text { and overserved }\end{array}$ \\
\hline 9 & $\begin{array}{c}\text { Buy a } \\
\text { Feature(Rein } \\
\text { \& Münch, } \\
\text { 2013) }\end{array}$ & $\begin{array}{l}\text { An innovation game } \\
\text { that can involve } \\
\text { customers and } \\
\text { stakeholders to } \\
\text { determine how } \\
\text { much is the feature } \\
\text { worth to help } \\
\text { prioritize }\end{array}$ & $\begin{array}{l}\text { Features, Price } \\
\text { for features, } \\
\text { Potential } \\
\text { Customers, } \\
\text { Virtual Money }\end{array}$ & $\begin{array}{l}\text { Game with } \\
\text { polling on } \\
\text { the } \\
\text { features }\end{array}$ & $\begin{array}{l}\text { Poll outcome as } \\
\text { a result }\end{array}$ \\
\hline 10 & Moscow & $\begin{array}{c}\text { Must have, should } \\
\text { have, could have, } \\
\text { Won't have }\end{array}$ & $\begin{array}{c}\text { Features, } \\
\text { prioritized based } \\
\text { on Must, Could, } \\
\text { Should and } \\
\text { Won't Have, } \\
\text { Estimated effort }\end{array}$ & $\begin{array}{l}\text { Spreadshe } \\
\text { et based }\end{array}$ & $\begin{array}{c}\text { Total estimated } \\
\text { efforts based on } \\
\text { priority }\end{array}$ \\
\hline
\end{tabular}

In an effort to identify the various factors which were identified in the Product prioritization frameworks which are existing a taxonomy is arrived which includes different markets, scales, evaluation criteria, etc., as outlined in the Figure 1: Product feature prioritization frameworks. The evaluation criteria can be determined based on the outcome in the choice of the framework. The hybrid selection of framework can also be used when they can be very effective. 


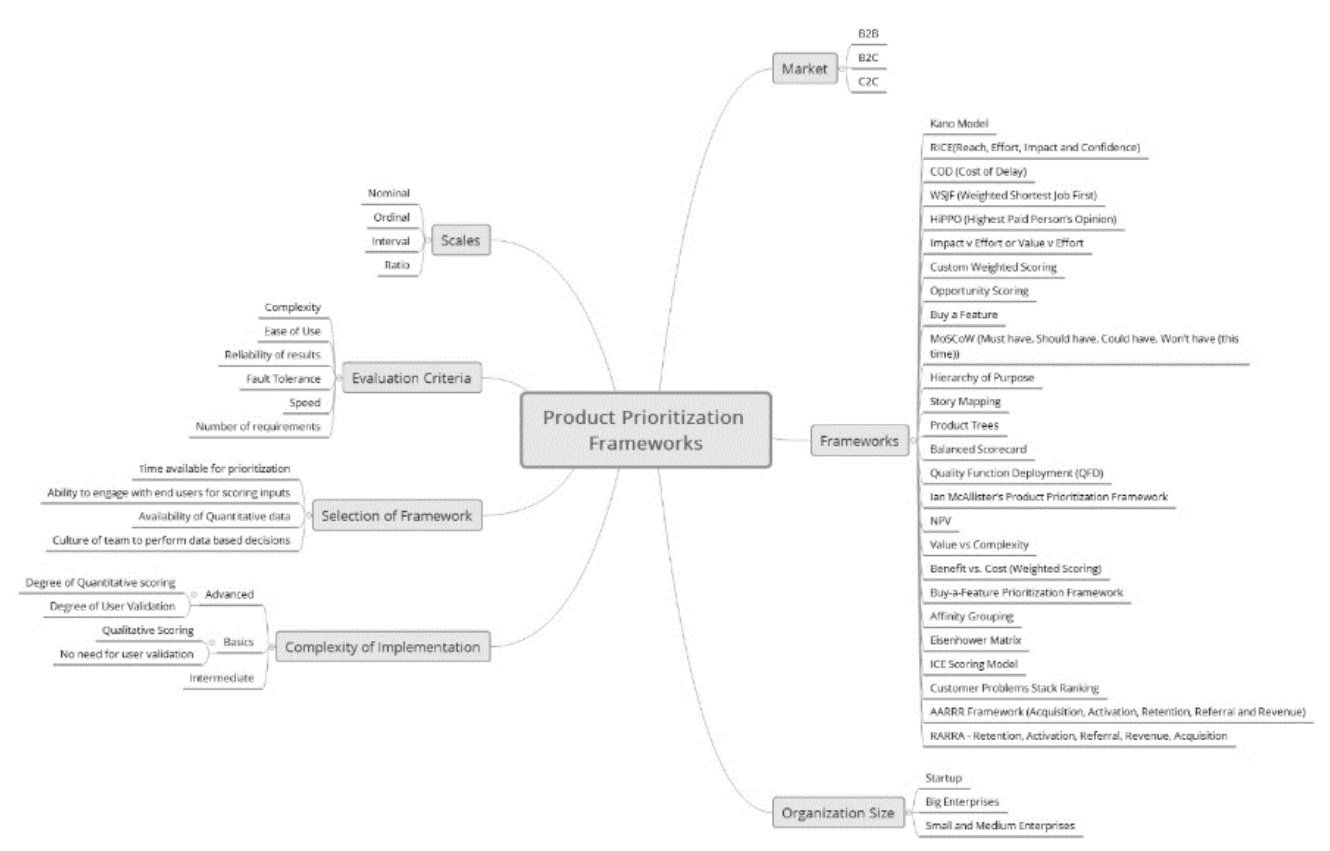

Figure 1: Product feature prioritization frameworks

Choice Kano Model needs an effort to prepare an publish a survey and infer the results from there on. Buy a product prioritization framework would be more of a gamification model with the necessary stakeholders. Custom weighted scoring methods or Weighted Shortest Job First methods can be combined for effective results which an provide a visual outcome.

\section{CONCLUSION}

Startups and product development organizations can use these findings to further the choice of prioritization frameworks which can be helpful in determining the features to be developed. The taxonomy can also help in various aspects of the frameworks and it could vary depending on the organization size. Frameworks are available which is based on Visual Output, Quantified Data factors, Graphs etc.

Depending on the inputs required the frameworks can be chosen and the output would be helpful for prioritization. Factors such as ease of use, time to prepare the prioritization outcome would be essential for the teams for better decision making towards product/market fit and arrive at well planned product roadmap. In the future there can be a case study which can experiment on of the priority framework which can help explore the framework choices outlined in this paper.

\section{FUNDING}

No fund received for this project

\section{COMPLIANCE WITH ETHICAL STANDARDS CONFLICTS OF INTEREST}

The authors declare that they have no conflict of interest. 


\section{ETHICAL APPROVAL AND HUMAN PARTICIPATION}

No ethics approval is required.

\section{DECLARATION OF INTERESTS}

The authors declare that they have no known competing financial interests or personal relationships that could have appeared to influence the work reported in this paper.

\section{REFERENCE}

[1] Zacarias D: Product Prioritization Techniques: A Map and Guided Tour. Folding Burritos (20)

[2] Crowne Mark. "Why software product startups fail and what to do about it. Evolution of software product development in startup companies." In IEEE International Engineering Management Conference 1:338-343. IEEE, 2002.

[3] Dingsфyr T, Hanssen GK, Dybå T, Anker G, Nygaard JO: Developing software with scrum in a small cross-organizational project. In European Conference on Software Process Improvement (pp. 5-15). Springer, Berlin, Heidelberg. 2006

[4] Giardino $C$, Wang $X$, Abrahamsson $P$ Why early-stage software startups fail: a behavioral framework. InInternational conference of software business (pp. 27-41). Springer, Cham. 2014

[5] Gupta V, Fernandez-Crehuet JM, Hanne T, Telesko R. Requirements Engineering in Software Startups: A Systematic Mapping Study. Applied Sciences 10(17):6125, 2020.

[6] Hudaib A, Masadeh R, Qasem MH, Alzaqebah A. Requirements prioritization techniques comparison. Modern Applied Science. 12(2):62, 2018.

[7] Kano N. Attractive quality and must-be quality. Hinshitsu (Quality, The Journal of Japanese Society for Quality Control).14:39-48, 1984.

[8] Karlsson J, Ryan K. A cost-value approach for prioritizing requirements. IEEE software, 14(5):67-74, 1997.

[9] Karlsson L, Höst M, Regnell B. Evaluating the practical use of different measurement scales in requirements prioritisation. InProceedings of the 2006 ACM/IEEE international symposium on Empirical software engineering (pp. 326-335), 2006.

[10] Qaddoura R, Abu-Srhan A, Qasem MH, Hudaib A. Requirements prioritization techniques review and analysis. In2017 International Conference on New Trends in Computing Sciences (ICTCS) (pp. 258-263). IEEE. 2017

[11] Rein AD, Münch J. Feature prioritization based on mock-purchase: A mobile case study. InInternational Conference on Lean Enterprise Software and Systems (pp. 165-179). Springer, Berlin, Heidelberg. 2013

[12] Rein AD, Münch J. Feature prioritization based on mock-purchase: A mobile case study. InInternational Conference on Lean Enterprise Software and Systems (pp. 165-179). Springer, Berlin, Heidelberg. 2013

[13] The biggest challenge for product managers? (2016). Retrieved 24 July 2020, from https://www.mindtheproduct.com/the-biggest-challenge-for-product-managers/

[14] Ulwick AW. What Is Outcome-Driven Innovation ${ }^{\circledR}$ (ODI). White Paper. 2009

[15] Wiegers K, Beatty J. Software requirements. Pearson Education; 2013. 